\title{
Tingkat pengetahuan, sikap dan perilaku ibu dalam pemberian imunisasi MR (Measles Rubella) pada anak usia 9 bulan-5 tahun
}

\author{
Umi Romayati Keswara', Eriyani², Super Adinata ${ }^{3 *}$
}

1Program Diploma III Keperawatan Fakultas Kedokteran Universitas Malahayati Bandar Lampung. Email: umiromayatikeswara.76@gmail.com

2Program Studi Diploma III Keperawatan STIKes Binalita Sudama, Medan. Email: hj.eriyanimkep@gmail.com

3Puskesmas Margodadi Tulang Bawang Barat, Lampung. *Email: superadinata@yahoo.com

\begin{abstract}
Measles Rubella vaccine in children ages 6 to 60 months related knowledge, attitudes and practices of mothers in Lampung-Indonesia
\end{abstract}

Background: Rubella is an acute and minor disease that often infects vulnerable children and young adults. High coverage and evenly at least $95 \%$ will create herd immunity and break the chain of rubella's spreading. Achievement of immunization obtained by UPTD in Puskesmas Margodadi was still low at $94.3 \%$.

Purpose: Knowing Measles Rubella vaccine in children ages 6 to 60 months related knowledge, attitudes and practices of mothers in Lampung-Indonesia.

Method: A quantitative research type with a case-control design with populations in this study were mothers who had children aged 9-60 months who were targeted in the implementation of mass MR immunization with a sample of 80 from 4 integrated service post or posyandu taken by Propositional Sampling. The instrument used was a questionnaire to determine the knowledge, attitudes, and behaviors of mothers in the provision of MR immunization. Data analysis used Chi-Square.

Results: Distribution frequency of characteristics of mothers who didn't give MR immunization with good knowledge were 18 respondents (45\%) and not so good knowledge were 22 respondents $(55 \%)$, distribution frequency of mothers with a positive attitude but not giving MR immunization were 17 respondents $(42,5 \%)$ and negative attitude mothers were 23 respondents (57.5\%). Chi-Square analysis showed that there was correlation between knowledge and mother's behavior with $\mathrm{p}$ value 0.012 and there was correlation between attitudes and mother's with $p$ value of 0.025 .

Conclusion: There were correlation of Measles Rubella vaccine in children ages 6 to 60 months related knowledge, attitudes and practices of mothers in Lampung-Indonesia. Suggestions for further research are to pay attention to predisposing factors, enabling factors, and reinforcing factors in their research.

\section{Keywords: Measles Rubella vaccine; Children; Mothers; Knowledge; Attitude; Practices}

Pendahuluan: Rubella merupakan penyakit akut dan ringan yang sering menginfeksi anak dan dewasa muda yang rentan. Cakupan yang tinggi dan merata minimal $95 \%$ akan membentuk herd immunity dan memutus rantai penularan penyakit rubella. Capaian imunisasi didapatkan UPTD Peskesmas Margodadi belum mencapai cakupan minimal sebesar $94,3 \%$.

Tujuan: Diketahui hubungan tingkat pengetahuan dan sikap terhadap perilaku ibu dalam pemberian imunisasi MR (Measles Rubella).

Metode: Penelitian kuantitatif dengan desain case-control, populasinya ibu yang memiliki anak usia 9 bulan-5 tahun yang menjadi sasaran dalam pelaksanaan imunisasi MR massal, dengan sampel 80 dari 4 posyandu yang diambil dengan cara proposional sampling. Instrumen yang digunakan berupa kuisioner untuk mengetahui pengetahuan, sikap, dan Perilaku ibu dalam pemberian imunisasi MR. Analisis data menggunakan Chi-Square.

Hasil: Distribusi frekuensi karakteristik ibu yang tidak memberikan imunisasi MR dengan pengetahuan baik sebesar 18 responden (45\%) dan yang buruk sebesar 22 responden (55\%), Distribusi frekuensi ibu dengan sikap positif namun tidak memberikan imunisasi MR sebesar 17 responden (42,5\%) dan ibu yang bersikap negatif sebesar 23 responden (57,5\%). Uji analisis Chi-Square terdapat hubungan pengetahuan dengan perilaku 
ibu dengan $\rho$-value sebesar 0,012 dan terdapat hubungan sikap dengan perilaku ibu dengan $\rho$-value sebesar 0,025 .

Simpulan: Ada hubungan tingkat pengetahuan dan sikap dengan perilaku ibu dalam pemberian imunisasi MR. Saran peneliti selanjutnya agar tetap memperhatikan factor predisposisi, factor pemungkin, dan factor penguat dalam penelitiannya.

\section{Kata Kunci: Pengetahuan; Sikap; Perilaku; Ibu; Imunisasi MR (Measles Rubella); Anak usia 9 bulan-5 tahun}

\section{PENDAHULUAN}

Rubella atau sering disebut campak jerman (German Measles) disebabkan oleh infeksi virus akut yang ringan, virus ini termasuk genus rubivirus dari family Togaviridae, virus terselubung dengan virion berukuran $60 \mathrm{~nm}$, dan bentuk virus ini bersifat pleomorfik atau berbentuk sferis. Penyakit yang biasanya menyerang anak - anak dan remaja sering menimbulkan gejala demam, sakit tenggorokan, malaise, dan sakit kepala atau bahkan tanpa gejala sehingga sering tidak terlaporkan (Soedarto, 2017). Apabila Rubella ini menyerang wanita hamil pada trimester pertama dapat menyebabkan keguguran, kematian janin atau sindrom rubella kongenital Congenital Rubella Syndrome (CRS). Pada bayi yang dilahirkan dengan CRS umumnya bermanifestasi sebagai penyakit jantung bawaan, katarak mata, bintikbintik kemerahan (purpura), microcephaly (kepala kecil), dan tuli (Kementerian Kesehatan Republik Indonesia, 2017).

Rubella sangat mudah menular, sebesar $90 \%$ penderita memiliki riwayat kontak dengan penderita lain. Penularan terjadi melalui droplet lewat udara yang dihirup. Orang yang pernah kontak dengan penderita lain biasanya tertular setelah 10-12 hari dari virus tersebut masuk (Elliott, Worthington, Osman, \& Gill, 2013).

Selama ini di Indonesia pemberian imunisasi campak sebagai salah satu program imunisasi nasional. Namun mengingat besarnya perkiraan beban penyakit Rubella dan tersedianya vaksin kombinasi Measles-Rubella (MR), maka diputuskan untuk mengganti vaksin Measles dengan vaksin kombinasi Measles-Rubella, yang dimulai dengan kegiatan imunisasi massal MR yang mana dari persentase yang mempunyai cakupan campak dosis pertama $>95 \%$ cenderung menurun, dari $45 \%$ tahun 2013 menjadi 28\% tahun 2015 (Kementerian Kesehatan Republik Indonesia, 2018). Sehingga kegiatan imunisasi massal MR adalah kesempatan yang sangat penting untuk menutup kesenjangan di atas, sehingga tidak ada daerah yang akan menjadi sumber penularan. Cakupan yang tinggi dan merata minimal 95\% akan membentuk herd immunity dan memutus rantai penularan penyakit campak dan rubella. Dan indonesia telah berkomitmen untuk mencapai eliminasi campak dan pengendalian rubella/Congenital Rubella Syndrome (CRS) pada tahun 2020, di mana sasaran imunisasi MR ini mencakup usia 9 bulan - 15 tahun (Kementerian Kesehatan Republik Indonesia, 2017).

Pada tahun 2010, Majelis Kesehatan Dunia berkomitmen untuk mengurangi kematian akibat campak hingga 95\% dari tingkat tahun 2000 pada tahun 2015. Pada tahun 2010, diperkirakan kematian akibat campak global turun $74 \%$ dari 535.300 kematian pada tahun 2000 menjadi 139.300 pada tahun 2010 (World Health Organization, 2012; Kementerian Kesehatan Republik Indonesia, 2017; Waluyo, 2018).

Di Indonesia setiap tahun melalui kegiatan surveilans dilaporkan lebih dari 11.000 kasus suspek rubella, dan hasil konfirmasi laboratorium menunjukkan 16\% - 43\%. Dari tahun 2010 sampai 2015, diperkirakan terdapat 30.463 kasus rubella. Data surveilans menunjukan $70 \%$ kasus rubella terjadi pada kelompok usia $<15$ tahun. Selain itu, berdasarkan studi tentang estimasi beban penyakit CRS di Indonesia pada tahun 2013 diperkirakan terdapat 2.767 kasus CRS, 82/100.000 terjadi pada usia ibu 15-19 tahun dan menurun menjadi 47/100.000 pada usia ibu 40-44 tahun (Kementerian Kesehatan Republik Indonesia, 2017)

Di Lampung tahun 2017 mencapain 101,9\%, namun demikian masih ditemukan angka kejadian campak setiap tahunnya pada tahun 2017 sebanyak $3 \times$ kejadian dan menurun ditahun berikutnya menjadi $1 \mathrm{x}$ kejadian, jumlah sasaran imunisasi MR mencapai 2.196.701 jiwa

Umi Romayati Keswara' Program Diploma 111 Keperawatan Fakultas Kedokteran Universitas Malahayati Bandar Lampung. Email: umiromayatikeswara.76@gmail.com

Eriyani $^{2}$ Program Studi Diploma III Keperawatan STIKes Binalita Sudama, Medan. Email: hj.eriyanimkep@gmail.com Super Adinata ${ }^{3}$ Puskesmas Margodadi Tulang Bawang Barat, Lampung. *Email: superadinata@yahoo.com 
Tingkat pengetahuan, sikap dan perilaku ibu dalam pemberian imunisasi MR

(Measles Rubella) pada anak usia 9 bulan-5 tahun

(Kementerian Kesehatan Republik Indonesia, 2017).

Data hingga akhir tahun 2018 dilaporkan kegiatan imunisasi MR di Kabupaten Tulang Bawang Barat rata - rata terlaksana melebihi target nasional sebesar 98,9\%, namun capain imunisasi MR yang didapatkan Puskesmas Margodadi masih rendah dibandingkan puskesmas lainnya yaitu berada pada urutan 3 terbawah di Kabupaten Tulang Bawang Barat (Dinas Kesehatan Kabupaten Tulang Bawang Barat, 2018).

Dari peneliti terdahulu menunjukkan bahwa tingkat pengetahuan mempengaruhi ibu dalam tindakannya memberikan imunisasi MR pada anaknya sebanayak $67,3 \%$ dan sikap ibu mempengaruhi tindakannya memberikan imunisasi MR sebanayak 50,9\% (Pramitasari, \& Puteri, 2017). Penelitian lainnya membahas tentang hubungan tingkat pengetahuan dengan minat keikutsertaan vaksinasi MR akan mempengaruhi ibu dalam tindakannya memberikan imunisasi MR pada anaknya sebanayak 78,7\% (Candrasari, 2018).

Hal ini sejalan dengan teori yang dipaparkan bahwa kesehatan individu atau masyarakat dipengaruhi oleh dua faktor pokok yaitu faktor perilaku dan non perilaku. Yang mana perilaku kesehatan masyarakat dipengaruhi oleh tingkat pengetahuan, sikap, keyakinan, kepercayaan, nilainilai tradisi dan dukungan suami maupun orangtuanya (Hidayat, 2014).

\section{METODE PENELITIAN}

Penelitian kuantitatif dengan metode diskriptif analitik dengan pendekatan case control. Penelitian ini sudah lulus kelaikan etik dari Komisi Etik Penelitian Kesehatan (KEPK) Universitas Malahayati dan dilaksanakan di 4 posyandu di Desa Margodadi wilayah kerja UPTD Puskesmas Margodadi Kabupaten Tulang Bawang Barat pada bulan Juni s.d Juli 2019. Populasi ibu yang memiliki anak balita usia antara 9 bulan - 5 tahun sebanyak 83 orang yang tidak memberikan imunisasi MR dan 524 balita yang diberikan imunisasi MR. Sampel sebanyak 80, dimana 40 balita yang tidak diberikan imunisasi MR dan 40 balita yang diberikan imunisasi MR. Menggunakan teknik proporsional sampling dan accidental sampling.

Analisa data mengunakan analisa univariat untuk mengetahui tingkat pengetahuan dan sikap ibu, serta menggunakan uji statistik chi-square untuk mengetahui adanya hubungan atau tidak. Dalam penelitian ini instrument yang digunakan adalah kuesioner. Kuesioner tingkat pengetahuan ibu sebanyak 21 pertanyaan dengan menggunakan pilihan jawaban pilihan ganda. Dengan nilai minimal jika jumlah soal benar sebesar $0-15$ soal dan nilai maksimal jika jumlah soal benar sebesar 16-21 soal. Kuesioner sikap ibu sebanyak 15 pernyataan dengan menggunakan pilihan dengan nilai 1 = sangat tidak setuju (STS), 2 = tidak setuju (TS), 3 = Ragu-ragu (RR), 4 = setuju (S), dan 5 = sangat setuju (SS) atau sebaliknya jika suatu pernyataannya negative. Dengan nilai minimal 0 dan maksimal 75 , dan nilai mean sebesar 56,04 .

Umi Romayati Keswara' Program Diploma III Keperawatan Fakultas Kedokteran Universitas Malahayati Bandar Lampung. Email: umiromayatikeswara.76@gmail.com

Eriyani $^{2}$ Program Studi Diploma III Keperawatan STIKes Binalita Sudama, Medan. Email: hj.eriyanimkep@gmail.com Super Adinata ${ }^{3}$ Puskesmas Margodadi Tulang Bawang Barat, Lampung. *Email: superadinata@yahoo.com 
(Measles Rubella) pada anak usia 9 bulan-5 tahun

HASIL

Tabel 1. Distribusi Karakteristik Responden $\mathrm{N}=80$

\begin{tabular}{lcc}
\hline Variabel & Frekwensi (f) & Persentase (\%) \\
\hline Pengetahuan & 47 & 58.7 \\
Baik & 33 & 41.3 \\
Buruk & & \\
Sikap ibu & 44 & 57.5 \\
Positif & 36 & 42.5 \\
Negatiif & & \\
& & \\
Pemberian imunisasi & & \\
Measles Rubella (MR) & 40 & 50.0 \\
Mendapatkan & 40 & 50.0 \\
Tidak Mendapatkan & & \\
\hline
\end{tabular}

Berdasarkan tabel 1 Karakteristik responden berdasarkan pengetahuan, sikap dan perilaku ibu. Faktor pengetahuan terbanyak adalah pengetahuan baik sebesar $58,7 \%$. Sikap ibu terbanyak adalah sikap pistif sebesar $57,5 \%$. Perilaku ibu rata rata seimbang yaitu sebesar $50 \%$.

Tabel 2. Hubungan Tingkat Pengetahuan, Sikap dan Perilaku Ibu Dalam Pemberian Imunisasi $M R \mathbf{N}=80$

\begin{tabular}{|c|c|c|c|c|c|c|c|c|}
\hline \multirow{3}{*}{ Variabel } & \multicolumn{4}{|c|}{$\begin{array}{c}\text { Pemberian imunisasi Measles } \\
\text { Rubella (MR) }\end{array}$} & \multirow{2}{*}{\multicolumn{2}{|c|}{ Total }} & \multirow{3}{*}{$p$-value } & \multirow{3}{*}{$\begin{array}{c}\text { OR } \\
(95 \% \mathrm{Cl})\end{array}$} \\
\hline & \multicolumn{2}{|c|}{$\begin{array}{c}\text { Tidak } \\
\text { Mendapatkan }\end{array}$} & \multicolumn{2}{|c|}{ Mendapatkan } & & & & \\
\hline & $\mathrm{n}$ & $\%$ & $\mathrm{n}$ & $\%$ & $\mathbf{N}$ & $\%$ & & \\
\hline $\begin{array}{l}\text { Pengetahuan } \\
\text { Baik } \\
\text { Buruk }\end{array}$ & $\begin{array}{l}18 \\
22\end{array}$ & $\begin{array}{l}22,5 \\
27,5\end{array}$ & $\begin{array}{l}29 \\
11\end{array}$ & $\begin{array}{l}36,25 \\
13,75\end{array}$ & $\begin{array}{l}47 \\
33\end{array}$ & $\begin{array}{l}58,75 \\
41,25\end{array}$ & 0,012 & $\begin{array}{c}3,222 \\
(1,268-8,188)\end{array}$ \\
\hline $\begin{array}{l}\text { Sikap lbu } \\
\text { Positif } \\
\text { Negatif }\end{array}$ & $\begin{array}{l}17 \\
23\end{array}$ & $\begin{array}{l}21,25 \\
28,75\end{array}$ & $\begin{array}{l}27 \\
13\end{array}$ & $\begin{array}{l}33,75 \\
16,25\end{array}$ & $\begin{array}{l}44 \\
36\end{array}$ & $\begin{array}{l}55 \\
45\end{array}$ & 0,025 & $\begin{array}{c}2,81 \\
(1,129-6,991\end{array}$ \\
\hline
\end{tabular}

Berdasarkan hasil diatas bahwa ibu yang memiliki tingkat pengetahuan tentang penyakit Rubella dan Imunisasi MR (Measles Rubella) dengan kategori baik, sebesar 18 responden $(22,5 \%)$ tidak memberikan imunisasi MR lebih rendah dibandingkan dengan ibu yang memberikan imunisasi MR sebesar 29 responden $(36,25,5 \%)$. Sedangkan ibu yang memiliki tingkat pengetahuan tentang penyakit Rubella dan
Imunisasi MR (Measles Rubella) dengan kategori buruk, sebesar 22 responden $(27,5 \%)$ tidak memberikan imunisasi MR lebih besar dibandingkan dengan ibu yang memberikan imunisasi MR sebesar 11 responden (13,75\%). Hasil uji chi-square diperoleh nilai $p=0,012$ (p.value < 0,05), dengan demikian dapat disimpulkan secara statistik dengan derajat kepercayaan $95 \%$ terdapat hubungan antara

Umi Romayati Keswara' Program Diploma 111 Keperawatan Fakultas Kedokteran Universitas Malahayati Bandar Lampung. Email: umiromayatikeswara.76@gmail.com

Eriyani $^{2}$ Program Studi Diploma III Keperawatan STIKes Binalita Sudama, Medan. Email: hj.eriyanimkep@gmail.com Super Adinata ${ }^{3}$ Puskesmas Margodadi Tulang Bawang Barat, Lampung. *Email: superadinata@yahoo.com 
Tingkat pengetahuan, sikap dan perilaku ibu dalam pemberian imunisasi MR

(Measles Rubella) pada anak usia 9 bulan-5 tahun

tingkat pengetahuan terhadap perilaku ibu dalam pemberian imunisasi MR (Measles Rubella).

Berdasarkan Sikap didapatkan bahwa ibu yang memiliki kategori sikap positif tentang Imunisasi MR (Measles Rubella), sebesar 17 responden $(21,25,5 \%)$ tidak memberikan imunisasi MR lebih rendah dibandingkan ibu yang memberikan imunisasi MR sebesar 27 responden $(33,75 \%)$. Sedangkan ibu yang memiliki kategori sikap negatif tentang Imunisasi MR (Measles Rubella), sebesar 23 responden $(28,7,5 \%)$ tidak memberikan imunisasi MR lebih besar dibandingkan pada ibu yang memberikan imunisasi MR sebesar 13 responden (16,25\%).

Hasil uji chi-square diperoleh nilai $p=0,025$ (p.value < 0,05), dengan demikian dapat disimpulkan secara statistik dengan derajat kepercayaan $95 \%$ terdapat hubungan antara sikap ibu dalam perilaku ibu dalam pemberian Imunisasi MR (Measles Rubella).

\section{PEMBAHASAN}

\section{Hubungan Tingkat Pengetahuan Dengan Perilaku Ibu}

Hasil penguji hipotesis terdapat hubungan antara tingkat pengetahuan terhadap perilaku ibu dalam pemberian imunisasi MR (Measles Rubella) dengan nilai nilai $p=0,012$ (p.value $<0,05$ ). Dan dengan nilai $O R$ sebesar 3,222 , hal ini menunjukkan bahwa tingkat pengetahuan ibu yang baik memiliki 3,222 kali kecenderungan untuk melakukan imunisasi MR (Measles Rubella) dibandingkan dengan ibu yang memilki tingkat pengetahuan yang buruk.

Terdapat responden sebesar $18(22,5 \%)$ yang memiliki pengetahuan baik namun tetap tidak melakukan imunisasi MR hal ini bisa disebabkan cara responden untuk memperoleh pengetahuan yang masih tradisional, sehingga dalam memahami suatu pengetahuan hanya berdasarkan nalar dan pemikirannya saja, tanpa mempertimbangkan manfaat dari imunisasi tersebut, namun juga terdapat responden sebesar 11 responden (13,75\%) dengan pengetahuan yang rendah tetapi tetap memberikan imunisasi MR hal ini di karenakan pengaruh yang baik dari lingkungan sekitar (tenaga kesehatan, tokoh masyarakat) sehingga mendorong untuk berperilaku terbuka sehingga berkenan dalam pemberian imunisasi MR.
Pengetahuan hasil dari pengindraan manusia atau hasil tahu yang diperoleh dari seseorang terhadap objek melalui indra, sehingga apabila pengetahuan semakin baik tinggi diharapkan akan mempengarui perilaku seseorang (Wawan, \& Dewi, 2011).

Dalam pelaksanaannya masih terdapat pihakpihak yang menyatakan kontra terhadap imunisasi. Kurangnya pengetahuan ibu tentang penatalaksanaan imunisasi MR tersebut serta menganggap imunisasi mendahului ketetapan Tuhan. Kontroversi juga diwarnai dengan adanya dugaan Kejadian Ikutan Pasca Imunisasi (KIPI), hal tersebut mengacu pada penelitian yang dilakukan bahwa imunisasi MMR (mumps, measles, and rubella atau gondong, campak, dan campak jerman) menjadi kontroversi terkait hasil penelitian adanya 12 anak menderita autis setelah diimunisasi MMR (Hadinegoro, 2016). Dalam penilitian terkait yang di lakukan di Inggris pada tahun 2012 menjelaskan bahwa masih banyak ibu yang ragu terhadap kombinasi imunisasi MMR (Meales Mumps Rubella), kekhawatiran ini dikarenakan adanya pemahaman publik tentang hubungan yang tidak berdasar tentang vaksin MMR (Brown, Long, Ramsay, Hudson, Green, Vincent, \& Sevdalis, 2012; Farizki, 2019).

Peneliti berkesimpulan bahwa pengetahuan atau stigma ibu terhadap imunisasi MR harus dipahami agar bisa mendukung perilaku ibu dalam pemberian imunisasi, serta informasi yang akurat dan penjelasan yang jelas terhadap bahaya penyakit Rubella dan penting nya imunisasi MR merupakan hal yang sangat dibutuhkan ibu / keluarga untuk mempengaruhi perilaku kesehatannya, namun masih ada sebagian ibu yang memiliki pengetahuan yang baik tetapi tidak melakukan imunisasi MR hal ini di karenakan ibu beranggapan bahwa imunisasi MR tidak sejalan dengan prinsip keyakinan dan kondisi atau keadaan si anak saat itu, dan adanya kekhawatiran terhadap kejadian paska imunisasi (KIPI). Namun terdapat ibu yang memiliki pengetahuan rendah atau kurang baik tapi tetap memberikan imunisasi MR, dikarenakan adanya dorongan atau motivasi serta dukungan yang baik dari lingkungan, keluarga, maupun tenaga kesehatan sehingga si ibu berkenan memberikan anak nya imunisasi MR.

Umi Romayati Keswara' Program Diploma III Keperawatan Fakultas Kedokteran Universitas Malahayati Bandar Lampung. Email: umiromayatikeswara.76@gmail.com

Eriyani ${ }^{2}$ Program Studi Diploma 111 Keperawatan STIKes Binalita Sudama, Medan. Email: hj.eriyanimkep@gmail.com

Super Adinata ${ }^{3}$ Puskesmas Margodadi Tulang Bawang Barat, Lampung. *Email: superadinata@yahoo.com 


\section{Hubungan Sikap Dengan Perilaku Ibu}

Hasil penguji hipotesis terdapat hubungan antara sikap ibu terhadap perilaku ibu dalam pemberian imunisasi MR (Measles Rubella) dengan nilai nilai $p=0,025$ (p.value $<0,05$ ). Dan dengan nilai OR sebesar 2,81 , hal ini menunjukkan bahwa sikap ibu yang positif memiliki 2,81 kali kecenderungan untuk melakukan imunisasi MR (Measles Rubella) dibandingkan dengan ibu yang memilki sikap yang negatif.

Sikap dimana terjadinya reaksi atau respon seorang yang masih tertutup terhadap suatu stimulus atau obyek. Perubahan sikap dipengarui oleh sumber dari pesan, dan pengindraan. Sikap ibu / orang tua memiliki hubungan dengan kelengkapan imunisasi, perbedaan sikap yang dimiliki ibu memiliki hubungan yang signifikan dengan perilaku dalam pemberian imunisasi, ibu yang memiliki sikap negatif mempunyai peluang lebih besar untuk untuk memiliki perilaku negatif dan sikap positif mempunyai peluang lebih besar untuk memiliki perilaku positif (Notoatmodjo, 2012).

Dari data terdapat responden yang memiliki sikap positif sebesar $17(21,25 \%)$ namun tidak memberikan imunisasi MR, hal ini disebakna karena hal ini di sebabkan oleh adanya Kondisi anak (sakit), keyakinan (Agama), dan kekawatiran atas KIPI (Kejadian Paska Imunisasi). beda halnya dengan responden yang bersikap negative yaitu 13 $(16,25 \%)$ namun tetap melakukan imunisasi MR yaitu hal ini bisa di sebabkan terbatasnya wawasan dan informasi (pengetahuan) sehingga berdampak pada sikap ibu dalam mengambil keputusan, namun hal ini bisa berubah karena adanya penjelasan yang berulang serta dorongan dari petugas kesehatan, tokoh masyarakat,dan kader kesehatan, petugas kesehatan. Hal ini bisa terjadi dikarenakan tingkat pengetahuan seseorang berpengaruh terhadap proses penilai atau bersikap terhadap stimulus atau objek kesehatan, sehingga indikator untuk sikap kesehatan juga sejalan dengan pengetahuan kesehatan yang dimiliki seseorang (Notoatmodjo, 2014).

\section{SIMPULAN}

Didapat distribusi responden berdasarkan tingkat pengetahuan ibu dengan kategori baik sebesar 18 responden (22,5\%) sedangkan dengan kategor1 buruk sebesar 22 responden $(27,5 \%)$, dan distribusi responden sikap positif ibu namun tidak memberikan imunisasi MR sebesar 17 responden $(21,25 \%)$, sedangkan ibu yang bersikap negatif sebesar 23 responden $(28,75 \%)$. ada hubungan antara tingkat pengetahuan terhadap perilaku ibu dalam pemberian imunisasi $\mathrm{mr}$ (measles rubella) dengan nilai $p=0,012$ berarti $p<a(0,05)$. ada hubungan antara sikap ibu dalam perilaku ibu dalam pemberian imunisasi $\mathrm{mr}$ (measles rubella) dengan nilai $p=0,025$ berarti $p<$ $a(0,05)$.

\section{SARAN}

Pentingnya meningkatkan pengetahuan responden dengan cara memberikan pendidikan kesehatan tentang imunisasi MR, responden harus aktif mencari informasi tentang imunisasi MR melalui media massa dan menerima secara terbuka setiap informasi yang disampaikan oleh petugas kesehatan.

\section{DAFTAR PUSTAKA}

Brown, K. F., Long, S. J., Ramsay, M., Hudson, M. J., Green, J., Vincent, C. A., \& Sevdalis, N. (2012). UK parents' decision-making about measles-mumps-rubella (MMR) vaccine 10 years after the MMR-autism controversy: A qualitative analysis. Vaccine, 30(10), 18551864.

Candrasari, A. (2018). Hubungan Pengetahuan Tentang Vaksin MR (Measles Rubella) dan Pendidikan Ibu Terhadap Minat Keikutsertaan Vaksinasi MR di Puskesmas Kartasura (Doctoral dissertation, Universitas Muhammadiyah Surakarta).

Dinas Kesehatan Kabupaten Tulang Bawang Barat (2018). Peningkatan Cakupan Imunisasi Rutin. Tulang Bawang Barat: Dinas Kesehatan Kabupaten Tulang Bawang Barat.

Elliott, T., Worthington, T., Osman, H., \& Gill, M. (2013). Mikrobiologi Kedokteran dan Infeksi Edisi 4. Jakarta: Penerbit Buku Kedokteran EGC.

Umi Romayati Keswara' Program Diploma III Keperawatan Fakultas Kedokteran Universitas Malahayati Bandar Lampung. Email: umiromayatikeswara.76@gmail.com

Eriyani ${ }^{2}$ Program Studi Diploma III Keperawatan STIKes Binalita Sudama, Medan. Email: hj.eriyanimkep@gmail.com Super Adinata ${ }^{3}$ Puskesmas Margodadi Tulang Bawang Barat, Lampung. *Email: superadinata@yahoo.com 
Farizki, M. F. (2019). Opini Orangtua Dalam Menanggapi Halalharamnya Vaksin Mr Dan Rubella Untuk Imunisasi Anak Di Desa Klambir V Kebun.

Hadinegoro, S. R. S. (2016). Kejadian ikutan pasca imunisasi. Sari Pediatri, 2(1), 2-10.

Hidayat, D. R. (2014). Ilmu Perilaku Manusia. Jakarta: CV. Trans Info Media.

Kementerian Kesehatan Republik Indonesia. (2017). Buku Ajar Imunisasi. Jakarta: Pusat Pendidikan dan Pelatihan Tenaga Kesehatan.

Kementerian Kesehatan Republik Indonesia. (2017). Data dan Informasi Profil Kesehatan Indonesia tahun 2016. Kementerian Kesehatan Republik Indonesia, Pusdatin Kemenkes RI. GEN, Jakarta: Pusdatin Kemenkes RI.

Kementerian Kesehatan Republik Indonesia. (2017). Petunjuk Teknis Kampanye dan Intoduksi Imunisasi Measles Rubella (MR). Jakarta: Direktorat Jenderal Pencegahan dan Pengendalian Penyakit Kementerian Kesehatan Republik Indonesia.

Kementerian Kesehatan Republik Indonesia. (2017). Profil Kesehatan Indonesia. Jakarta: Kementerian Kesehatan Republik Indonesia.

Kementerian Kesehatan Republik Indonesia. (2017). Status Campak dan Rubella Saat Ini Indonesia. Jakarta: Kementerian Kesehatan Republik Indonesia.
Kementerian Kesehatan Republik Indonesia. (2018). Hasil Utama Riskesdas 2018. Jakarta: Balitbangkes Kementerian Kesehatan.

Notoatmodjo, S (2012). Promosi Kesehatan dan Perilaku Kesehatan. Jakarta: Rineka Cipta.

Notoatmodjo, S. (2014). IImu Perilaku. Jakarta: Penerbit PT. Rineka Cipta.

Pramitasari, D. A., \& Puteri, I. R. P. (2017). Hubungan pengetahuan dan Sikap Ibu Dengan Kepatuhan Dalam Mengikuti Imunisasi Measles-Rubella (MR) Massal di Posyandu Wilayah kerja Puskesmas Nganglik II Kabupaten Sleman Yogyakarta. The shine cahaya dunia d-iii keperawatan, 2(2).

Soedarto, S. (2017). Ensiklopedia Penyakit Infeksi. Jakarta: CV Sagung Seto.

Waluyo, A. I. (2018). Hubungan Tingkat Pengetahuan Dengan Kepatuhan Ibu Dalam Pemberian Imunisasi Campak Di Desa Jatisari Kecamatan Kebumen Kabupaten Kebumen (Doctoral dissertation, STIKES Muhammadiyah Gombong).

Wawan, A., \& Dewi, M. (2011). Teori dan pengukuran pengetahuan, sikap dan perilaku manusia. Yogyakarta: Nuha Medika.

World Health Organization. (2012). Global measles and rubella strategic plan: 2012.

Umi Romayati Keswara' Program Diploma III Keperawatan Fakultas Kedokteran Universitas Malahayati Bandar Lampung. Email: umiromayatikeswara.76@gmail.com

Eriyani $^{2}$ Program Studi Diploma III Keperawatan STIKes Binalita Sudama, Medan. Email: hj.eriyanimkep@gmail.com Super Adinata ${ }^{3}$ Puskesmas Margodadi Tulang Bawang Barat, Lampung. *Email: superadinata@yahoo.com 